\title{
sciendo
}

DOI 10.2478/sbe-2019-0020

SBE no. 14(1) 2019

\section{ASSESSING THE IMPACT OF SERVICE QUALITY DIMENSIONS ON CUSTOMER SATISFACTION IN COMMERCIAL BANKS OF MAURITIUS}

\author{
VENCATAYA Lomendra* \\ PUDARUTH Sharmila* \\ JUWAHEER Roubina TD* \\ DIRPAL Ganess* \\ SUMODHEE Nabeelah Meh Zabeen* \\ *University of Mauritius
}

\begin{abstract}
:
In today's hyper competitive banking arena, banking institutions are focusing on improving service quality. Providing excellent quality of service is important in creating and sustaining competitive advantage in the banking industry of Mauritius due to intense competition between local and international banks. Hence, the paper explores the impact of Service Quality (SQ) Dimensions on customer satisfaction. Using the SERVQUAL model, the paper seeks to examine the impacts of reliability, responsiveness, assurance, empathy and tangible aspects on customer satisfaction in banks of Mauritius. A sample of 200 banking customers was randomly selected and data were analyzed through SPSS version 22. The SERVQUAL model has been found as reliable factors and appropriate tool to measure, evaluate, support, and improve the quality of services in banking industry. Results indicated that all five service quality factors have significantly positively influenced customer satisfaction in banks. Regression analysis was also conducted and depicted that empathy is a significant predictor of customer satisfaction among the five SQ dimensions.
\end{abstract}

Key words: Service Quality (SQ) Dimensions, SERVQUAL, Customer Satisfaction, Banking Industry, Mauritius

\section{Introduction}

Due to intense competition, sophisticated nature of customers, flexible and unpredictable demand and similarity of services offered by banks, enhanced service quality to satisfy customers is regarded as the main concern to retain loyal customers 
(Kheng et al., 2010). Thus, it is important that banks focus their endeavors to improve service quality and delight their customers (Radomir et al., 2010). There has been numerous studies explaining the impact of service quality dimensions on customer satisfaction (Ojo 2010, Arslan et al., 2014, Molaee et al.,2013). To the author's best knowledge, no study has yet analysed the impact of service quality dimensions on customer satisfaction in the boundary of a developing nation such as Mauritius. Hence, this paper seeks to understand in-depth the key dimensions and factors of service quality in the banks of Mauritius and how does the identified factors impact on customers' satisfaction level of banking customers.

The banks need to strive for constant progress in enhancing service quality and to do so, there is an urge to determine the predictive factors that affect quality of service for customers in banking institution. The significance of this paper is that it will provide insights to banks on the appropriate banking service that suit customer needs, determining the association between service quality dimensions and customer satisfaction levels in Mauritius. It will also help the management to identify areas of improvement and assist them to know how, when and where to put more resources so as to improve the service quality and thus being able to offer quality customer service, which is the major theme of this paper.

\section{Literature review}

During past few decades the interest of academics and researchers has amplified to measure the link between service quality and customer satisfaction in the area of service settings such as the banking sector (Levesque and McDougall, 1996 ; Oliver and Swan, 1989 ; Cadotte et al., 1987 ; Swan and Trawick, 1980). Numerous researchers have further debated whether service quality is a cause of customer of satisfaction (Cronin and Taylor, 1992; Parasuraman et al., 1985), which helps to identify a link between both constructs. Overwhelming body of literatures have depicted that both concepts are distinct conceptually but are very closely related to each other (Parasuraman et al., 1994 ; Shemwell et al., 1998) ; where any increase in one (service quality) leads to an increase in another (satisfaction) (Sureshchandar et al., 2002).

Along these lines, numerous researchers also found meaningful and strong relationship between service quality and customer satisfaction in banking institutions(Avkiran ,1994;Levesque and McDougall, 1996; Jamal, 2004 ; Al-Hawari and Ward, 2006 and Razak et al., 2007)and they all advocated that banks should focus on service quality as an input to customer satisfaction for long-term benefits and business success (Khurana, 2013). Likewise, Avkiran (1994) highlighted in his study that the banking industry forms a link between service quality and customer satisfaction and according to Wang et al. (2003). Banks have realized the importance of providing superior service quality to impact customer satisfaction level so as to successfully survive in today's global and highly competitive environment.

Furthermore, Levesque and McDougall (1996) investigated the impact of key service quality dimensions on customer satisfaction, using the SERVQUAL model in banking institutions and found a substantial impact of service problems on customer 
satisfaction and their intentions to switch. The SERVQUAL model was originally introduced by Parasuraman et al. (1985) and developed for the service sectors (Van Iwaarden et al., 2003) which is put into practice by many researchers to test service quality and identify its impact on customer satisfaction. The pioneer study of Parasuraman et al., (1988) introduced ten SQ Dimensions, and researchers such as Oppewal and Vriens (2000) empirically investigated the relationship between service quality and customer satisfaction by using the original SERVQUAL instrument with 10 dimensions. However, later on, some of the dimensions were found to be interrelated factors by researchers such as Parasuraman et al. (1985) and Berry et al. (1985). Conceptually, five SQ Dimensions are mostly used to assess quality of service namely :

Tangibility: consist of physical appearances and facilities, staff appearance and equipments.

Reliability: ability of delivering the services as promised with consistency and accuracy.

Responsiveness: staff willing to help, guide, provide punctual and quick services to customers.

Assurance: Employee's knowledge, politeness and ability to inspire trust.

Empathy: caring and personal attentions provided by the company to the customers.

Consequently, as replacement for SERVQUAL, Brown et al. (1993) and Carman (1990) introduced the SERVPERF model to assess quality of service in the banking sector, but according to various studies, its reliability was questionable. Customer satisfaction and perceived service quality are seen to be different construct, and as stated by Parasuraman et al. (1994), "the former is an evaluation based on a specific transaction while the latter is a general assessment developed over a period of time". Moreover, in a study by Avkiran (1994), it was depicted that the BANKSERV model comprising of only four dimensions pertaining to staff conduct, credibility, communication and customer accessibility was developed to measure service quality in retail banking in Australia. However, the SERVQUAL model is mostly used and has proven to be more applicable to assess service quality in the banking sector.

Along these lines, Angur et al. (1999) tested the SERVQUAL model and the study aim was to measure the $S Q$ dimensions perceived by customers in the retail banking industry in India, where the data indicated that responsiveness and reliability were the most important dimensions, and assurance appeared to be the least important. Lau et al. (2013) study was based on SERVQUAL model that identified the influence of the five dimensions in banking service environments on customer satisfaction. Voluminous studies were conducted wherein the SQ dimensions were tested in and found to be significant predictors of customer satisfaction in retail banking (Levesque and McDougall, 1996 ; Krepapa et al., 2003 ; McDougall and Levesque, 2000 ; Ndubisi and Wah, 2005). Both Angur et al. (1999) and Lau et al. (2013) promulgated in their studies that SERVQUAL is indeed the best model and the most appropriate assessment tool to measure service quality in the retail banking industry.

Nevertheless, only few studies have investigated the relationship between each of the five SERVQUAL dimensions and customer satisfaction in the banking sector, which have reported some mixed results based on numerous studies (Johnston, 1997 ; Lassar et al., 2000 ; Zhou, 2004 ; Arasli et al., 2005). For instance, the study of Zeithaml et al. (2006) 
and Berry et al. (1985) shows that "reliability" has constantly proven to be the most important service dimension among the five SQ Dimensions to impact on the customer satisfaction level. Researchers like Arasli et al. (2005) pointed up that assurance, reliability, empathy and tangibles dimensions of service quality were better predictors of customer satisfaction in the Cyprus banking sector, whereas Yavas et al. (1997) found tangibles, empathy and responsiveness to be the most important predictors of customer satisfaction among bank customer in Turkey. Additional support comes from Zhou (2004), who reported that reliability and assurance were important predictors of satisfaction for bank customer in China and the study of Jamal and Naser (2002) proved that reliability, tangibility and empathy are positively related with customer satisfaction.

SERVQUAL is a well-known research instrument for evaluating service quality in banking industry and the model perfectly covers the dimensions that are considered by a customer in evaluating quality of service in a bank. Voluminous studies have utilized SERVQUAL for evaluating service quality in the banking industry (Arasli et al. 2005 ; Zhou 2004). However, so far, there are insufficient studies which have assessed the link between SQ Dimensions and Customer Satisfaction and no study has yet assessed the impact of $S Q$ dimensions for improving customer Satisfaction for retail banking. Hence, this will form the conceptual framework of this paper, by using the five dimensions of SERVQUAL provided by Parasuraman et al., (1988) to assess the impact of each of the service quality dimensions (Tangibility, Reliability, Responsiveness, Assurance and Empathy) on customer satisfaction in retail banking sector of Mauritius, which is a framework also adopted in the empirical study of Lau et al. (2013) ; and Tariq et al. (2013). Thus, the following hypotheses as shown in Fig 1 are developed to test the impact of each $S Q$ dimensions on customer satisfaction in retail banking sector of Mauritius.

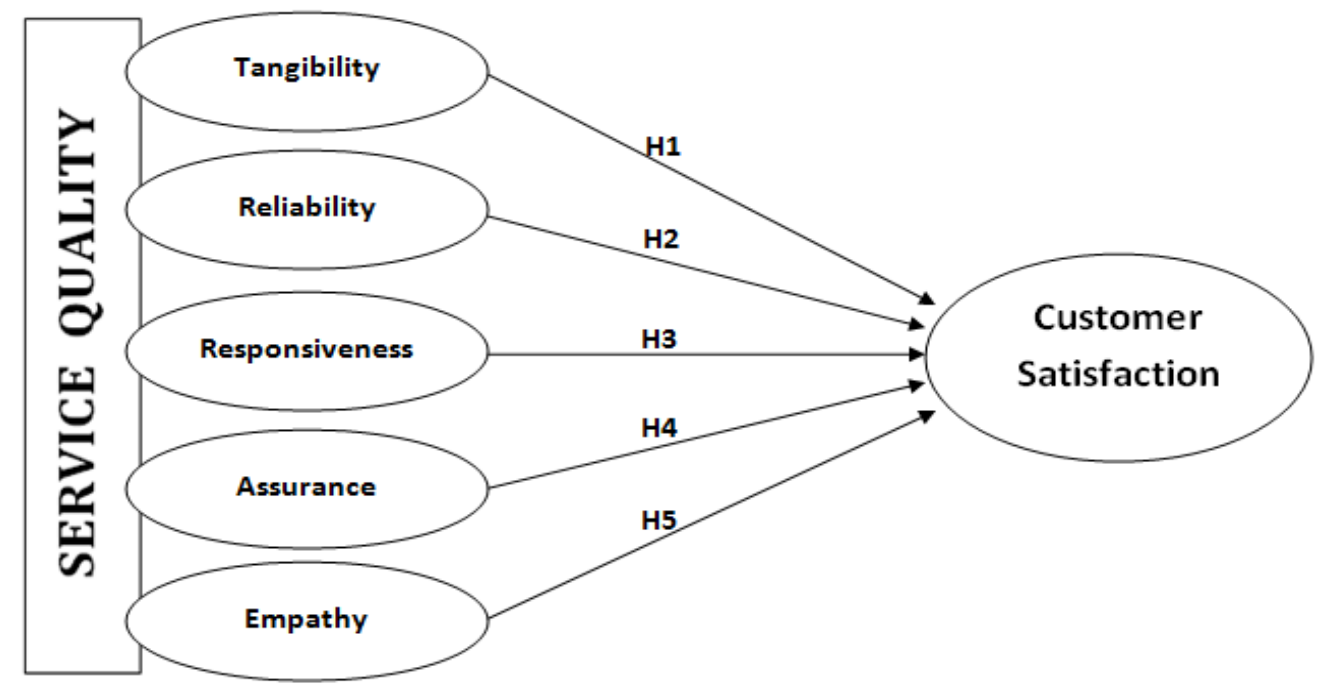

Fig.1 Research Framework 


\section{Research Methodology}

In line with the present research, the paper adopts both the descriptive and explanatory research design to investigate the relationship between $S Q$ dimensions and level of customer satisfaction where a questionnaire comprising of three sections was developed. The questionnaire items were constructed and adapted from the existing intensive literature review. In this paper, the satisfaction level of customers toward the service quality provided by the banks in Mauritius was measured on a five-point Likert Scale $(1=$ Strongly Disagree to $5=$ Strongly Agree). Statistical techniques were used to process the data using factor analysis with the statistical program SPSS 22. The present research mainly uses the multiple regression analysis to test and evaluate the hypothesis in the research framework.

\section{Sampling plan}

The target population comprises of all the bank customers in Mauritius selected on a random basis, with a sample size of 200 bank customers in Mauritius between the ages of 16 and 60 encompassing of both males and females. The sampling procedures were certainly aimed at satisfying the main demographic variables and the targeted sample frame comprises of all relevant types and the right mix of the banking customers ensuring that it reflects and represents the whole population. In the process of data collection, structured questionnaires were mainly used as research instrument for this paper and, were distributed to the respondents via social media (e.g. Facebook), email, as well as face to face interview.

\section{Internal Consistency of the Questionnaire}

The Cronbach's alpha for the entire questionnaire was 0.892 which demonstrates that the questionnaire is highly reliable for researchers to carry forward their investigations. As highlighted by Nunnally (1978), a minimum coefficient of 0.70 is recommended, with 0.60 being moderately reliable and a coefficient of 0.80 and above being considered as strongly reliable.

\section{Empirical findings}

\section{Part A : Demographic Profile of Respondents}

A profile of the respondents is presented in Table 1 where the majority of respondents being students representing $52 \%$, followed by self-employed $(17 \%)$ and professionals (16\%), aging between $18-30$ years old representing $79.5 \%$ of the sample. A majority of $70 \%$ are from urban areas and 30\% from rural zones. Moreover, in the survey questionnaire, a big majority of respondents rated MCB $(68.5 \%)$ as their most preferred bank in Mauritius, followed with SBM (25\%), HSBC (3.5\%), MAUBANK (2\%), Hong-Kong Bank $(0.5 \%)$ and Others which englobe Bank One, National Bank of Mauritius, Bank of Mauritius representing $0.5 \%$. 
Studies in Business and Economics no. 14(1)/2019

Part A : Demographic Profile of Respondents

\begin{tabular}{|c|c|c|c|c|c|}
\hline Gender & Frequency & $\begin{array}{c}\text { Percentage } \\
\%\end{array}$ & Residential Location & Frequency & $\begin{array}{c}\text { Percentage } \\
\%\end{array}$ \\
\hline Male & 83 & 41.5 & Urban & 140 & 70.0 \\
\hline Female & 117 & 58.5 & Rural & 60 & 30.0 \\
\hline Age Group & Frequency & $\begin{array}{c}\text { Percentage } \\
\% \\
\end{array}$ & Monthly Income & Frequency & $\begin{array}{c}\text { Percentage } \\
\%\end{array}$ \\
\hline $18-30$ & 156 & 79.5 & $<$ Rs. 10,000 & 109 & 54.5 \\
\hline $31-40$ & 29 & 13.0 & Rs $10,001-20,000$ & 39 & 19.5 \\
\hline $41-50$ & 13 & 6.5 & Rs $20,001-30,000$ & 27 & 13.5 \\
\hline \multirow[t]{2}{*}{50 and Above } & 2 & 1.0 & Rs $30,001-40,000$ & 8 & 4.0 \\
\hline & & & Rs $40,001-50,000$ & 5 & 2.5 \\
\hline Marital Status & Frequency & $\begin{array}{c}\text { Percentage } \\
\%\end{array}$ & $>\operatorname{Rs} 50,000$ & 12 & 6.0 \\
\hline Single & 153 & 76.5 & & & \\
\hline Married & 41 & 20.5 & Occupation & Frequency & $\begin{array}{c}\text { Percentage } \\
\%\end{array}$ \\
\hline \multirow[t]{2}{*}{ Divorced } & 6 & 3.0 & Self-employed & 34 & 17.0 \\
\hline & & & Businessman & 14 & 7.0 \\
\hline Qualifications & Frequency & $\begin{array}{c}\text { Percentage } \\
\%\end{array}$ & Professional & 32 & 16.0 \\
\hline Below Graduate & 103 & 51.5 & Housewife & 6 & 3.0 \\
\hline Graduate & 70 & 35.0 & Student & 104 & 52.0 \\
\hline Above Graduate & 27 & 13.5 & Others & 10 & 5.0 \\
\hline
\end{tabular}

$n=200$

\section{Part B : Empirical Findings}

Factor analysis was essentially developed to investigate upon the determining factors and the most important dimensions which customers take into consideration while transacting with bank in Mauritius. The five main SQ dimensions which influence and impact the bank customers more are : tangibility, reliability, responsiveness, assurance and empathy as shown in tables below.

The above factor analysis tables of the 5 service quality dimensions (factor 1 factor 5) all have explained percentage variances and factor loadings satisfying the cut-off point of 0.5 . All the factors were considered as significant and chosen for interpretation, with 'empathy' having the highest Eigenvalue of 3.5 with an explained variance of $70.1 \%$ and 'tangibility' having the lowest Eigenvalue of 1.7 with an explained variance of $56.5 \%$. However, one item having a factor loading less than 0.40 under the 'tangibility' factor was excluded due to its insignificance while for the other four factors, all the items were retained considering the fact that all the variables had factor loading more than 0.40 . The multiple regression analysis was also applied to explore the 5 service quality factors influencing the customers to transact with the banks in Mauritius. 
Table 1 : Factor Analysis Result for the 21 items representing the 5 Service Quality Dimensions of the bank

\begin{tabular}{lr}
\hline Scale items/Factor & Factor 1 \\
\hline Tangibility & .833 \\
\hline The bank has good physical appearance. & .635 \\
The equipment/ ATM machines are available and accessible in the bank & .774 \\
\hline The informative brochuresandpamphlets are available in the bank. & $\mathbf{0 . 6 0 1}$ \\
\hline Reliability coefficient (Cronbach's Alpha) & $\mathbf{1 . 6 9 6}$ \\
& $\mathbf{5 6 . 5 2 6}$ \\
\hline & $\mathbf{0 . 5 8 9}$ \\
\hline The Kaiser-Meyer-Olkin measure of sampling adequacy & $\mathbf{0 0 0}$ \\
\hline The Barlett's test of sphericity (significance level) & Factor 2 \\
\hline & .821 \\
\hline Reliability & .531 \\
\hline The service is delivered as promised by the bank. & .795 \\
The bank timeliness, rapidity and effectiveness of service delivery/to process transactions. & .828 \\
The bank provides accurate information. & .695 \\
\hline The service is delivered by the bank with quality and sophistication. & $\mathbf{0 . 7 7 1}$ \\
The bank assures confidentiality and privacy. & $\mathbf{2 . 7 5 6}$ \\
\hline Reliability coefficient (Cronbach's Alpha) $\quad$ Eigenvalue & $\mathbf{5 5 . 1 1 9}$ \\
\hline$\quad$ Variance Explained & $\mathbf{0 . 7 4 7}$ \\
\hline The Kaiser-Meyer-Olkin measure of sampling adequacy & $\mathbf{0 0 0 0}$ \\
\hline The Barlett's test of sphericity (significance level) &
\end{tabular}

\begin{tabular}{|c|c|}
\hline Responsiveness & Factor 3 \\
\hline The employees provide punctual services andhandlemy requests without delay in the bank. & .837 \\
\hline The employees of the bank are helpful and are willing to help and guide. & .773 \\
\hline The employeesefficientlyhandle queries via telephone in the bank. & .762 \\
\hline The employees provide fast and effective service counters in the bank. & .718 \\
\hline The staff s in the bank are highly responsive to my needs, requirements and queries. & .837 \\
\hline Reliability coefficient (Cronbach's Alpha) & 0.834 \\
\hline Eigenvalue & 3.097 \\
\hline Variance Explained & 61.932 \\
\hline The Kaiser-Meyer-Olkin measure of sampling adequacy & 0.808 \\
\hline The Barlett's test of sphericity (significance level) & .000 \\
\hline Assurance & Factor 4 \\
\hline The employees in the bank are able to inspire trust. & .877 \\
\hline The employees in the bank are friendly, courteous, and polite. & .885 \\
\hline The staff of the bank has good communication skills and positive approach. & .912 \\
\hline Reliability coefficient (Cronbach's Alpha) & 0.870 \\
\hline Eigenvalue & 2.384 \\
\hline Variance Explained & 79.453 \\
\hline The Kaiser-Meyer-Olkin measure of sampling adequacy & 0.731 \\
\hline The Barlett's test of sphericity (significance level) & .000 \\
\hline
\end{tabular}


Studies in Business and Economics no. 14(1)/2019

\begin{tabular}{lr}
\hline Empathy & Factor 5 \\
\hline & \\
\hline The bank has effective help desks and call centers & .795 \\
The bank provides good treatment. & .883 \\
I can easily interact with the bank. & .831 \\
The bank inspires trust and faith. & .825 \\
The bank understands the specific needs and perspectives. & .850 \\
\hline Reliability coefficient (Cronbach's Alpha) $\quad$ Eigenvalue & $\mathbf{0 . 8 9 2}$ \\
$\quad$ Variance Explained & $\mathbf{3 . 5 0 7}$ \\
& $\mathbf{7 0 . 1 4 6}$ \\
\hline The Kaiser-Meyer-Olkin measure of sampling adequacy & $\mathbf{0 . 8 4 6}$ \\
\hline The Barlett's test of sphericity (significance level) &. $\mathbf{0 0 0}$ \\
\hline
\end{tabular}

\section{Multiple Regression Analysis}

Multiple regression analysis was conducted to test the research hypotheses. Due to the fact that the sample size used for this study is not large, it is considered sufficient to apply the multiple regression analysis. As presented in Table 5, the analysis is proven to be statistically significant $(P<0.001)$ and with the five service quality determinants explaining about $32 \%\left(R^{2}=0.320\right)$ of overall customer satisfaction.

Table 2 : Service Quality Dimensions Regression Analysis Results

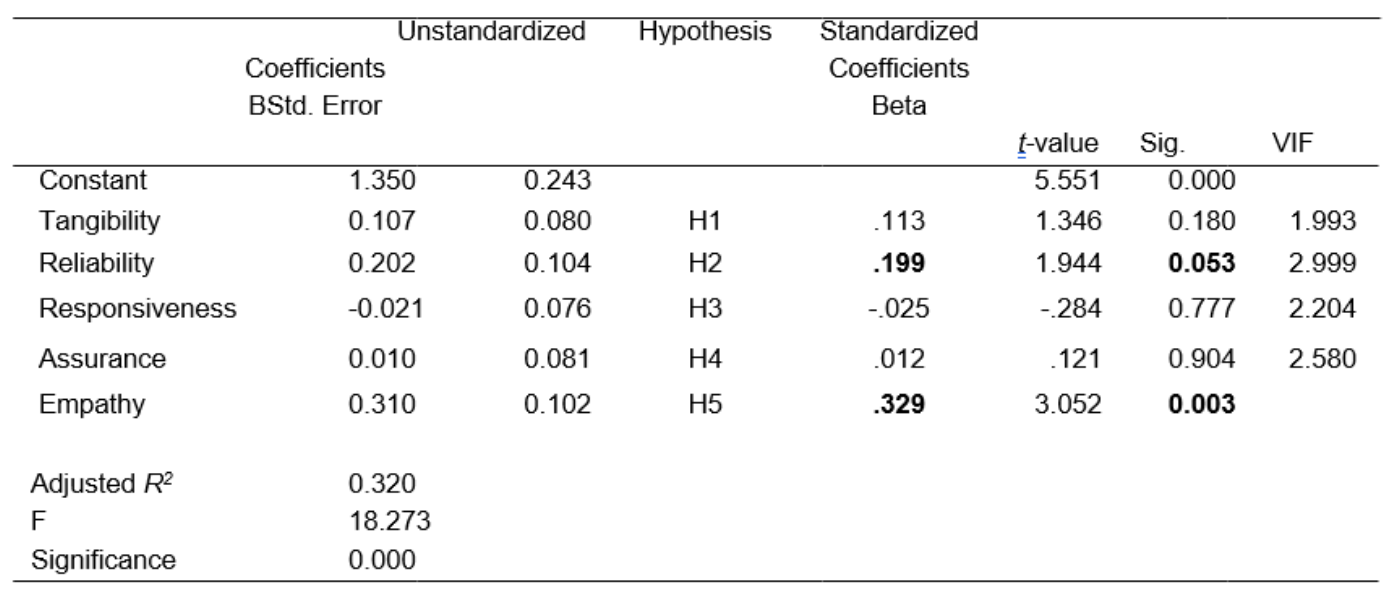

The coefficients values illustrate that Empathy (H5), with $32.9 \%$, and Reliability $(\mathrm{H} 2)$, with $19.9 \%$, are better predictors of Satisfaction. Thus, higher support is provided for Hypothesis $5(P<0.01)$ suggesting that Empathy, the way the banks care and connect with its customers, is a better predictor of satisfaction. Hypothesis 5 shows a higher statistically significant positive relationship (sig. $=0.003$ ). Support is also provided for Hypothesis $2(P<0.05)$, suggesting that banks which provide consistent and reliable quality of service are more likely to develop customer satisfaction.

Low support has been found, however for Hypotheses 1, 3 and 4 that focus on the physical and tangible aspect of a bank, their approachable and receptive aspect and guarantee or assurance provided. Therefore based on these theories, the following equation can be formed : 


$$
\begin{aligned}
& \qquad \mathbf{Y = b} \mathbf{0}+\mathbf{b} 1 \mathbf{x} \mathbf{1 + \mathbf { b } 2 \mathbf { 2 } 2} \\
& \text { Overall satisfaction }=1.35+0.202(\mathrm{OR})+0.310(\mathrm{E}) \\
& \text { Where OR = Overall Reliability and } \mathrm{E}=\text { Empathy }
\end{aligned}
$$

The above equation implies that, for each one unit increase in overall reliability of the service quality dimensions, the overall satisfaction of the customers will increase by $0.202(20 \%)$ while for each one unit increase in overall empathy of the bank, the customer's satisfaction level will increase by $0.310(31 \%)$.

\section{Managerial implications of the study}

The study has brought about some interesting findings that retail banks in Mauritius should take into consideration. The empirical findings have demonstrated that among the five SQ Dimensions, 'Empathy' ( $r=0.329, p<0.01)$, followed by 'Reliability' $(r=$ $0.199, p<0.05$ ), have the most positive and significant impact on customer satisfaction and, these two factors are better predictors of customer satisfaction based on the multiple regression analysis. The factors in the high importance and high potential to deliver satisfaction therefore require special attention. Hence, the bank managers must ensure that employees are being able to bond, connect and provide appropriate help to the customers, as well as provide reliable and consistent service quality in order to generate higher level of customer satisfaction.

It is very crucial for bank managers to ensure sufficient and effective help desks is provided to the customers and accurately train the bank staffs to provide good treatment and better connect and interact with the customers to understand their requirements and needs. In order to pertinently interact with the customers, the retail banks can make use of social media (e.g. via Facebook page) to connect with the customers, show interest in their viewpoints and answer their queries in a more effective and direct way. Moreover, the banks can also provide feedback questionnaire either online or placed near counters or enquiry desks to show they are openly welcoming customers to drop their feedback. It is fundamental for retail banks to nurture one-to-one relationship with the customers to create a lasting emotional bond between the banks and the customers, hence catering for the empathy aspect of service quality to highly impact on the customer satisfaction level.

Another major implication of the present study relates to the ability of the retail banks to provide reliable service quality so as to impact customer satisfaction. In this respect, the regression results depicted that there is a prerequisite for the retails banks to be more rapid in processing transactions by adopting effective technological improvement, upgraded systems and fast working and efficient employees at service counters so as to be more reliable. Therefore, suitable and multi skill trainings should be provided to the bank staffs to increase productivity and have better impact on customer satisfaction. In addition, by embedding high security measures and develop more effective privacy policies, retail banks can enhance the perception and satisfaction of the customers, encouraging and reassuring them to transact with the bank in the long term. These practical recommendation will help retail banks in Mauritius to improve on competitive edge, increase customer satisfaction and maintain long-term profits. 


\section{Conclusion}

Far from having reached its apex, assessing the five SQ Dimensions impact on customer satisfaction has still a long road to travel in both research and practice. There is strong empirical evidence in this paper demonstrating that 'Empathy' and 'Reliability' aspect of service quality of the bank are the two major areas where banks' managers need to focus on to attain greater level of customer satisfaction. Eminently, the empirical findings can be useful and a pragmatic tool for policy makers, bank managers and the various players in the highly competitive banking arena of Mauritius to re-orient their strategies and opt to adopt a more customer-focus approach.

\section{Overall Limitations of Research}

The paper has some potential limitations which consist of the generalization of its findings as it focus was only in the banking sector. Other service sectors can also show different results. Moreover, the SERVQUAL model was not applied to assess individual banks in Mauritius. The paper focus only on the customers' perceptions and those of policy makers, bank staffs have not yet been tapped. Additionally, the study was only conducted at the preliminary level of investigating the impact of $S Q$ dimensions on customer satisfaction level, in which the latter was treated as a single construct.

\section{Directions for Future Research}

Future research can go deeper in assessing individual banks and come up with more explicit results and researchers can expand future similar studies to cross-industry levels. Additional research could also be extended toward bank staffs as service quality also involve employees. Likewise, Future research can examine the influence of SQ dimensions on other important aspects, such as customer loyalty, and customer retention, which would be useful in view of customer satisfaction as a mediating variable making the research framework more robust and intense.

\section{References}

Al-Hawari, M., Ward, T., (2006), The Effect of Automated Service Quality on Australian Banks' Financial Performance and the Mediating Role of Customer Satisfaction, Marketing Intelligence and Planning, Vol. 24, no. 2, pp. 127-147.

Angur, M. G., Nataraajan, R., Jahera, J. S., (1999), Service quality in the banking industry : An assessment in a developing economy. International Journal of Bank Marketing, Vol. 19, no.3, 1116-1123.

Arasli, H, TuranKatrircioglu, S., Mehtap-Smadi, S., (2005). A comparison of service quality in the banking industry: Some evidence from Turkish - and Greek - speaking areas in Cyprus, International Journal of Bank Marketing, Vol. 23, No. 7, pp. 508-526.

Arasli, H., Mehtap-Smadi, S. and Katircioglu, S. T., (2005), Customer service quality in the Greek Cypriot banking industry, Managing Service Quality, Vol. 15, no.1, pp. 41-56. 
Arslan et al., (2014), Effect of Service Quality Dimensions on Customer Satisfaction : A Comparative Analysis of Pakistan Telecom Sector, Research on Humanities and Social Sciences (Paper), 2224-5766 ISSN. Vol.4, no.19.

Avkiran, N.K., (1994), Developing an Instrument to Measure Customer Service Quality in Branch Banking, Inter. J. Bank Mark, Vol. 12, no. 6, pp. 10-18.

Berry, L.L., Zeithaml, V.A. and Parasuraman, A., (1985), Quality counts in services too, Business Horizons, May-June, pp. 44-52.

Brown, T.J., Churchill, G.A. and Peter, J.P., (1993). Improving the measurement of service quality, Journal of retailing, 69(1) 126-139

Cadotte, E. R., Woodruff, R.B. and Jenkins, R.L., (1987). Expectations and Norms in Models of Consumer Satisfaction, Journal of Marketing Research, 24 (3).

Carman, J.M., (1990). Consumer perceptions of service quality: An assessment of the SERVQUAL dimensions, Journal of Retailing, Vol. 66, Spring, pp. 35-55.

Cronin, J.J. and Taylor, S.A. (1992), Measuring service quality : A reexamination and extension, Journal of Marketing, Vol. 56, July, pp. 55-68

Jamal A., (2004), Retail Banking and Customer Behavior : A Study of Self Concept, Satisfaction and Technology Usage, The International Review of Retail, Distribution and Consumer Research, Vol. 14, no. 3, pp. 357-379.

Jamal, A. and Naser, K., (2002), Customer satisfaction and retail banking: an assessment of some of the key antecedents of customer satisfaction in retail banking, International Journal of Bank Marketing, Vol. 20, no.4, pp. 146-160

Kheng et al., (2010), The impact of service quality on customer loyalty, International Journal of Marketing, Vol. 2, no. 2, pp. 57-65.

Levesque, T., McDougall, G. H. G., (1996), Determinants of Customer Satisfaction in Retail Banking, The International Journal of Bank Marketing, Vol. 14, no. 7, pp. 12-20.

Lau, M.M., Cheung, R., Lam, A.Y.C., Chu, Y.T. (2013), Measuring Service Quality in the Banking Industry: A Hong Kong Based Study, Contemporary Management Research, Vol. 9, no. 3. pp. 263-282.

Ojo, O., (2010). The Relationship Between Service Quality and Customer Satisfaction in the Telecommunication Industry : Evidence From Nigeria. Broad Research in Accounting, Negotiation, and Distribution, 1(1).

Oliver, R.L., Swan, J.E., (1989), Equity and Disconfirmation Perceptions as Influences on Merchant and Product Satisfaction, Journal of Consumer Research, Vol. 16, pp.372-383.

Oppewal, H., Vriens, M., (2000), Measuring Perceived Service Quality Using Integrated Conjoint Experiments, International Journal of Bank Marketing, Vol. 18, No. 4, pp. 154-69.

Parasuraman, A., Zeithaml, V. A., \& Berry, L. L.,1985. A conceptual model of service quality and its implications for future research, Journal of Marketing, 49, 41-50.

Parasuraman, A., Zeithaml, V. A., \& Berry, L. L., 1988. SERVQUAL : A multiple-item scale for measuring consumer perceptions of service quality, Journal of Retailing, 64 (1), p.12-40.

Radomir et al.,2010. Improving bank quality dimensions to increase customer satisfaction, Vol. 1 No. 1. Pp. $126-148$.

Razak, R.M., Chong, C.S., Lin, B., (2007), Service Quality of a Local Malaysian Bank : Customers' Expectations, Perceptions, Satisfaction and Loyalty, International Journal of Services and Standards, Vol. 3, No. 1, pp. 18-38.

Johnston, R., (1997), Identifying the critical determinants of service quality in retail banking : Importance and effect, International Journal of Bank Marketing, pp. 111-116.

Shemwell, D.J., Yavas, U., Bilgin, Z., (1998), Customer-service provider relationships : An empirical test of a model of service quality, satisfaction and relationship oriented outcome, International Journal of Service Industry Management, Vol. 9, no. 2, pp.155-68. 
Khurana, S., (2013), Service Quality Versus Customer Satisfaction in Banking Sector: A Literature Review, The IUP Journal of Marketing Management, Vol. XII, No. 4. Available online at: https://www.researchgate.net/publication/261181211 Service quality vs Customer satisfa ction in banking sector A literature Review.

Sureshchandar, G.S., Chandrasekharan, R., Anantharaman, R.N., (2002), The relationship between service quality and customer satisfaction -a factor specific approach, Journal of Services Marketing, Vol. 16, no. 4, pp.363-379.

Swan, J.E., Trawick, I.F., (1980), Satisfaction Related to Predictive vs Desired Expectations, Indiana University Bloomington, IN, pp. 7-12.

Van Iwaarden, J., Van der Wiele, T., Ball, L., Millen, R., (2003). Applying SERVQUAL to Web sites : An exploratory study, International Journal of Quality and Reliability Management, Vol. 20, no. 8, pp. 919-935. Available online at : http://dx.doi.org/10.1108/02656710310493634

Wang, Y., Lo, H-P, Hui, Y., (2003), The Antecedents of Service Quality and Product Quality and Their Influences on Bank Reputation : Evidence From the Banking Industry in China, Managing Service Quality, Vol. 13, No. 1, pp. 2-83.

Yavas, U., Bilgin, Z., Shemwell, D.J., (1997), Service quality in the banking sector in an emerging economy : a consumer survey, International Journal of Bank Marketing, Vol. 15, No.6, pp. 217-23.

Zeithaml, V.A., Bitner, M.J., Gremler D.D., (2006), Services marketing, 4th edition, McGrawHill.

Zhou, L., (2004), A dimension-specific analysis of performance-only measurement of service quality and satisfaction in China's retail banking, Journal of Services Marketing, Vol. 18, pp. 534546. 